\title{
Infusing moral content into primary school English textbooks: A critical discourse analysis
}

\author{
Urip Sulistiyo $^{1 *}$, Supiani $^{2}$, Ahmad Kailani ${ }^{3}$, and Reni Puspitasari Dwi Lestariyana ${ }^{4}$ \\ ${ }^{1}$ English Education Department, Faculty of Teacher Training and Education, Universitas Jambi, Jalan Jambi- \\ Ma-Bulian, KM. 15, Jambi, Indonesia \\ ${ }^{2}$ Universitas Islam Kalimantan MAB Banjarmasin,Jalan Adhyaksa Kayu Tangi No.2, \\ South Kalimantan, Indonesia \\ ${ }^{3}$ Universitas Muhammadiyah Banjarmasin,Jalan Gubernur Haji Sarkawi Alalak Utara, \\ South Kalimantan, Indonesia \\ ${ }^{4}$ Komunitas Meneliti dan Menulis Banyuwangi, East Java, Indonesia
}

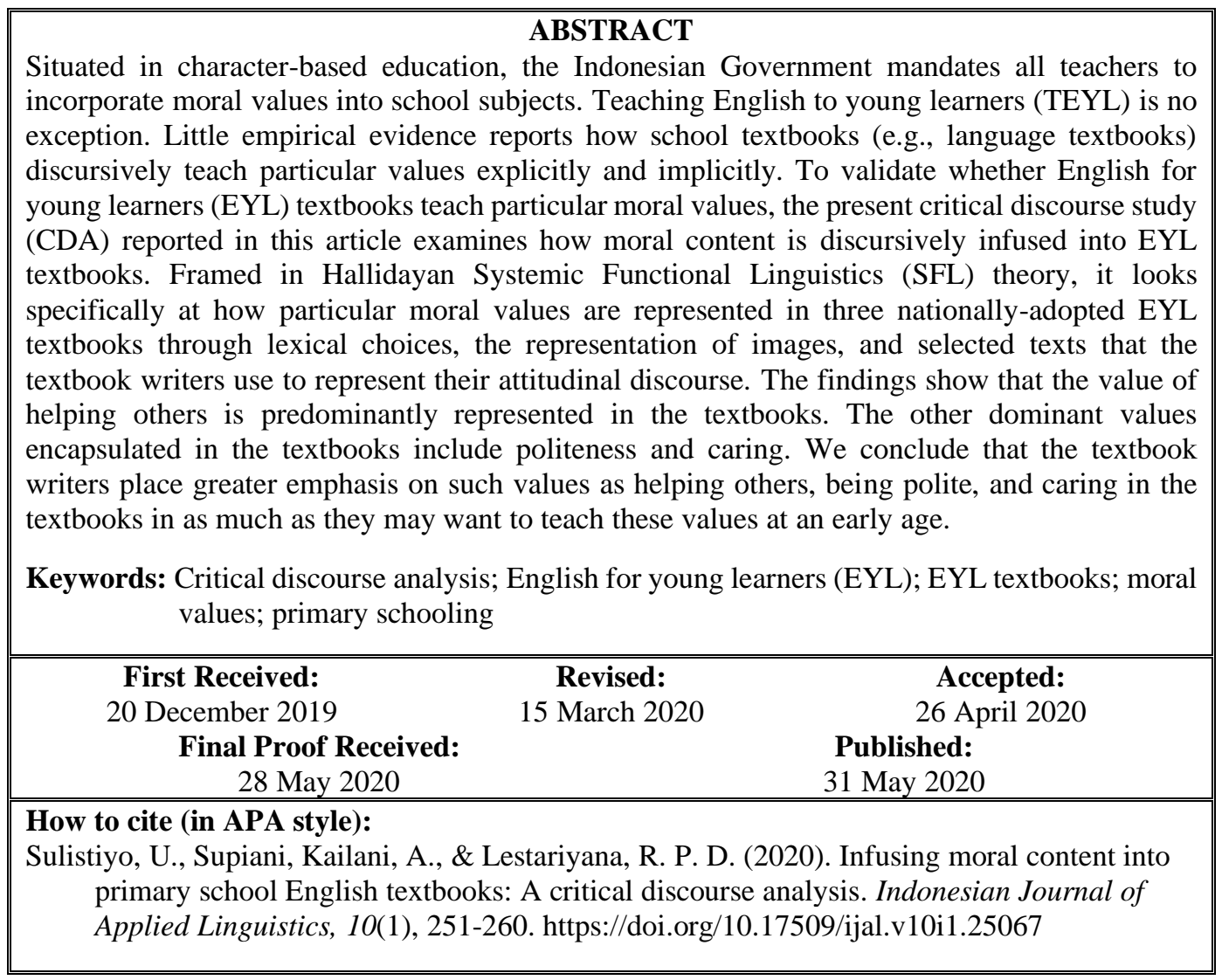

\section{INTRODUCTION}

Not only do textbooks serve as sources of learning and teaching (Orton, 2010; Putra \& Lukmana,2017), but also they can be agents of instilling particular values/attitudes (moral values) in students (Setyono \& Widodo, 2019; Widodo, 2018). The integration of moral or character education into school subjects in order to prepare youth to address life's ethical and moral problems has been a global issue. Indonesia is no exception for integrated moral or character education. Before the enactment of the 2013 Curriculum in Indonesia, such school subjects such as Religious Education and Civic Education were the mere subjects that taught moral or character education. However, as the 2013 Curriculum was officially enacted, character education is integratedly taught across the curriculum in order to build students' character identities.

The grand character education guidelines endorse 18 values, such as religiosity, honesty, tolerance, discipline, hardwork, creativity, independence, democracy, curiosity, patriotism, nationalism, appreciativeness, friendliness, peace making, love to read, environmental awareness, social awareness, and responsibility (Kemendiknas, 2011). The character education policy has challenged

\footnotetext{
* Corresponding Author

Email: urip.sulistiyo@unja.ac.id
} 
school teachers to incorporate moral values spelled out in the grand Indonesian curriculum guidelines into school subjects (see Qoyyimah, 2016; Widodo, 2016 b). In other words, school teachers teach not merely subject content but also moral values (Qoyyimah, 2016; Widodo, 2018).

Moral values is communally accepted behaviour in different social contexts, such as interacting with other ethnic groups, participating in communal events, and communicating with parents or other people with different socio-economic and cultural backgrounds. These values may vary from society to society (Widodo et al., 2018). Moral values as social norms may shape someone's thinking, feeling and behaviour (Widodo, 2018). Liu (2005) exemplifies diligence, respect for authority, modesty, tolerance and honesty as moral values. These values are formed or modulated through sociohistorical and sociocultural interactions (Gu, 2016). In the educational landscape, one of the educational goals is to cultivate those moral values (Lovat, 2017).

In Indonesian EFL contexts, the main objective of English lessons at an early stage (primary schooling) is to introduce young learners to foreign language literacy in addition to their native and national languages. More specifically, the teaching of English in primary schools is geared towards pupils' linguistic development of the ability to understand simple oral and written languages (Huda 1999; Sulistiyo et al., 2019). Even though the goal of learning English is to enable students to be competent English speakers, teaching English in primary schools should consider building students' morality or moral identity. Alwasilah (2012), for example, posits that primary education should focus on children's character building before they are exposed to foreign culture associated with English, for instance. In language education (e.g., English education), moral education can serve as a platform for language teachers to build and develop students' characters while learning a new language, such as English (Thongrin, 2012).

Inasmuch as the integration of moral values into school subjects in primary and secondary education, English as a school subject is no exception. Globally, the teaching of English cannot be divorced from teaching moral or character values. Scholars in the field (Johnston 2003; Shaaban 2005) argue that the teaching of the English language has been viewed as a carrier of moral education. Among language curriculum artifacts, language textbooks as silent partners of teachers (Orton, 2010) play a central role in delivering English lessons to students. These English lessons mainly teach students language skills/areas, such as listening, speaking, reading, writing, vocabulary, and grammar in the classroom (Parlindungan et al, 2018). Generally, language teachers rely on the use of language textbooks. They may adopt or adapt lessons in the textbooks in order to teach particular language skills or areas, thereby meeting students' language learning needs.

Wittingly or unwittingly, language teachers may be aware or unaware that language textbooks comprise particular ideological values. On a daily basis, both language teachers and students use language textbooks that allow both actors get exposed to particular ideological values, including moral values (Feng, 2017). Prior research (Ma, 2012, Widodo, 2018) has shown that language textbooks as the manifestation of the intended/hidden curriculum could instill particular moral values in both teachers and students. Thus, language textbooks can teach not only language-related content (skills) but also moral values.

In education settings, researchers often use these terms: character education and values education interchangeably when talking about moral education. Throughout this paper, we also use both terms. When we discuss character education, we also deal with moral values. The term, 'moral,' is associated generally with the concept of worldviews and values in an English language curriculum (Xiong, 2012). In the educational system, moral education is very often integrated into national curricula and taught in every subject at all formal educational levels (Doan, 2005). Moral education provides students with knowledge about what is morally wrong and ethically right according to particular moral norms and standards. As Shaaban (2005) emphasizes, moral education is one of the strategic ways for educators to teach basic values (e.g., fairness, honesty, showing respect to others) and principles in which learners can build in order to develop their sense of social and personal responsibilities.

As mentioned earlier, the cultivation of character or moral values is one of the educational goals through moral or character education (Lovat, 2017). This educational goal is also spelled out in Indonesia's educational policy and curriculum documents (Widodo, 2018). Character or moral education should be integrated explicitly into all school subjects including English (Mambu, 2015). The Indonesian Government would like to emphasize that value or character education is included in school subjects in order to inculcate character or moral values into learners (Qoyyimah, 2016). Moral education is included in the primary and secondary school curricula (Qoyyimah, 2016). In other words, all schools have to incorporate moral education into all school subjects. This has been implemented in primary and secondary education since 2011 (Pusat Kurikulum, 2010). The Ministry of National Education of the Republic of Indonesia allows schools to manage and choose how moral values or character education is integrated into particular school subjects (Suparno, 2011). Character education or moral education is the core of a school curriculum to develop students' sense of responsibility, respect, fairness, and other values. Given this policy, 
language teachers also needs to include moral education in their teaching practices. In doing so, textbooks can be one of the agents of manifesting moral education because both teachers and learners engage regularly with this curriculum artifact as a main resource of learning and teaching.

To attain national character education goals, schools should review their curriculum and balance between moral values and national qualities (the Curriculum Development Council, 2012). Moreover, teachers should select appropriate learning materials that include moral content such as showing respect to other people who have different ethnic or cultural backgrounds (Feng, 2017; Setyono \& Widodo, 2019). In addition, Teachers as textbooks users and designers play an important role in the evaluation and use of textbooks (Sulfasyah et al., 2018). In the Indonesian EFL context, moral values and attitudes must be taught to students. Thus, EFL teachers have to integrate moral values into language learning materials. In Indonesia, the issue of cultivating morals content in EFL textbooks for young learners has become a catalyst for building strong and solid national characteristics, but EFL teachers still experience a lacuna in the teaching of English. For example, in primary schools, English is no longer a compulsory school subject. English can be offered as an optional school subject or a co-curricular subject. No national TEYL guidelines are available (Sulistiyo et al., 2019). EYL teachers have autonomy in designing learning materials. Although the English subject is not a compulsory subject in primary schools, teachers should have awareness and commitment to integrating moral values into English language teaching.

A number of researchers (see Akbari, \& Tajik, 2012; Johnston, 2003; Widodo et al., 2018) have advocated the integration of moral or character education into English classrooms. For example, Shaaban (2005), who argues that the English as a foreign language (EFL) classroom is a natural place for moral education where language teachers can help learners build particular moral values. Widodo et al. (2018) suggest that the use of textbooks as main sources of learning in EFL classrooms plays a crucial role in infusing moral values into EFL learning activities (materials). Therefore, language teachers can view textbooks as agents of moral or character building. Owing the need for the inclusion of moral education in English as a school subject, language teachers need to explore more language teaching practices, which help students learn moral values represented in spoken, written, and visual texts. Thus, textbooks can be a medium of teaching values in English instruction in which these values can be manifested through texts, tasks, and images (visuals) (Widodo, 2018).

Among others, main moral values commonly taught in schools include honesty, self-esteem, perseverance, equality, interdependence and tolerance of difference (Feng, 2017). Infusing positive values and attitudes into school subjects can help learners develop their character needs. For example, in key stages 1 and 2 (Primary $1-6$ ), positive values and attitudes contain perseverance, benevolence, respect, and other values in which students should build so as to solve real-life problems. By key stages 3 and 4 (Secondary $1-6$ ), students should develop their ability in cognitive and analytical attitudes in different situations continuously (the Curriculum Development Council 2012).

In teaching English to young learners (TEYL) context, previous studies (Copland et al., 2014; Hawanti, 2014; Lestariyana \& Widodo, 2018; Sulistiyo et al., 2019; Widodo, 2016; Zein, 2017) have focused on language policy, teaching strategies, and language assessment. But, relatively little evidence reports critical studies into primary school English textbooks, except for studies by Hermawan and Noerkhasanah (2012) and Xiong and Qian (2012). While there have been dozens of studies on critical discourse studies into language textbook evaluation (Xiong, 2012; Xiong \& Qian, 2012), close investigations into moral content in primary English textbooks remain rare. To fill this empirical gap, the present discourse study examines the representation of moral values in government-mandated EFL textbooks situated in Indonesian primary schools.

\section{METHOD}

This critical discourse study (CDA) looks at moral content in English for Young Learners (EYL) textbooks. CDA was selected as an analytical tool because a textbook is viewed as an educational text which contains a myriad of discursive meanings through verbal and non-verbal languages (Widodo, 2018). Textbooks are seen as the product of educational discourse which can be textually examined. A textbook as a curriculum artifact also is a cultural product situated in the educational domain. Culturally, these textbooks contain a particular value system manifested through the use of specific language verbally and visually. To reveal this cultural value (e.g., moral values), Hallidayan systemic functional linguistic framework (Halliday, 1978) was deployed to look at how lexical items and images as visual texts represent the attitudinal discourses of the textbook writers (Widodo, 2018).

For closer textual analysis, SFL-informed system of appraisal by Martin and White (2005) was used to understand the authors' strategies for positioning their attitudinal discourse within the textbooks examined. Informed by this framework, we looked at three elements of attitudinal discourse, such as affect, judgment, and appreciation. Affect deals with emotion and feelings of the participants in texts while judgment serves to assess behavior and attitude 
of the participants that comply with social esteems and norms. Appreciation is aesthetic values of things.

The data of this study were extracted from three series of textbooks called Grow with English published by ERLANGGA (Grades 4, 5, and 6) geared for elementary school students. The authors of these textbooks are Indonesian EFL practitioners and seasoned writers. These textbook series were selected for an in-depth analysis based on the following considerations:

1. Although English is no longer included in the current national curriculum (The Curriculum 2013) in elementary schooling, the selected textbooks are still widely used in Indonesian elementary schools. The current curriculum endorses the infusion of character education into English language teaching if schools offer English as an optional or co-curricular subject. The textbook series were the product of the previous curriculum, School-Based Curriculum in 2006, and then the revised curriculum called The Curriculum 2013 (see Widodo, 2016).

2. The textbooks series were published by Erlangga Press that is nationally accredited in Indonesia. They regularly publish school textbooks. The series were also written by Indonesian writers who understand the context of ELT in Indonesia.

For data analysis, we read and re-read all the texts in the textbook series to see certain patterns or themes. Then, we sorted out a few samples of the texts that portray particular moral values based on the national grand character education guidelines. Then, we closely examined the selected text samples in order to understand the way the textbook writers infuse moral content into the textbooks. As a whole, we looked at the selected written texts, images, and particular languages that depict the textbook writers' attitudinal discourse.

\section{FINDINGS AND DISCUSSIONS}

This section presents the findings of frequency analysis and narrative analysis of the textbooks regarding moral values represented in the written texts, images, and particular languages in the textbook series. Both findings are taken from values as tallied in Table 1 below.

Table 1

Words portraying moral content in the EYL textbooks (Grades 4,5, and 6)

\begin{tabular}{|c|c|c|c|c|c|c|c|c|}
\hline \multirow{2}{*}{ Values } & \multicolumn{2}{|c|}{ Grade 4} & \multicolumn{2}{|c|}{ Grade 5} & \multicolumn{2}{|c|}{ Grade 6} & \multirow{2}{*}{$\begin{array}{c}\text { Total } \\
\text { Frequency }\end{array}$} & \multirow{2}{*}{$\begin{array}{c}\text { Total } \\
\text { Percentage }\end{array}$} \\
\hline & Freq & $\%$ & Freq & $\%$ & Freq & $\%$ & & \\
\hline Nuclear family & 1 & $2 \%$ & 0 & $0 \%$ & 0 & $0 \%$ & 1 & $1 \%$ \\
\hline Togetherness & 2 & $4 \%$ & 0 & $0 \%$ & 0 & $0 \%$ & 2 & $1 \%$ \\
\hline Respecting and valuing diversity & 3 & $7 \%$ & 0 & $0 \%$ & 1 & $4 \%$ & 4 & $3 \%$ \\
\hline Friendliness & 4 & $9 \%$ & 4 & $5 \%$ & 2 & $7 \%$ & 10 & $7 \%$ \\
\hline Warm relationship & 4 & $9 \%$ & 0 & $0 \%$ & 1 & $4 \%$ & 5 & $3 \%$ \\
\hline Caring & 4 & $9 \%$ & 9 & $12 \%$ & 2 & $7 \%$ & 15 & $10 \%$ \\
\hline Enthusiasm & 1 & $2 \%$ & 0 & $0 \%$ & 1 & $4 \%$ & 2 & $1 \%$ \\
\hline Loving family & 4 & $9 \%$ & 0 & $0 \%$ & 1 & $4 \%$ & 5 & $3 \%$ \\
\hline Problem solving mentality & 1 & $2 \%$ & 0 & $0 \%$ & 1 & $4 \%$ & 2 & $1 \%$ \\
\hline Respecting privacy & 3 & $7 \%$ & 0 & $0 \%$ & 0 & $0 \%$ & 3 & $2 \%$ \\
\hline Politeness & 10 & $22 \%$ & 5 & $6 \%$ & 1 & $4 \%$ & 16 & $11 \%$ \\
\hline Being helpful/Helping others & 5 & $11 \%$ & 19 & $25 \%$ & 1 & $4 \%$ & 25 & $17 \%$ \\
\hline Discipline & 3 & $7 \%$ & 0 & $0 \%$ & 0 & $0 \%$ & 3 & $2 \%$ \\
\hline Respecting others & 0 & $0 \%$ & 10 & $13 \%$ & 0 & $0 \%$ & 10 & $7 \%$ \\
\hline Appreciation & 0 & $0 \%$ & 5 & $6 \%$ & 0 & $0 \%$ & 5 & $3 \%$ \\
\hline Appreciating a profession & 0 & $0 \%$ & 2 & $3 \%$ & 0 & $0 \%$ & 2 & $1 \%$ \\
\hline Solidarity & 0 & $0 \%$ & 1 & $1 \%$ & 0 & $0 \%$ & 1 & $1 \%$ \\
\hline Sincerity & 0 & $0 \%$ & 1 & $1 \%$ & 0 & $0 \%$ & 1 & $1 \%$ \\
\hline Collaboration & 0 & $0 \%$ & 3 & $4 \%$ & 0 & $0 \%$ & 3 & $2 \%$ \\
\hline Sympathy & 0 & $0 \%$ & 3 & $4 \%$ & 0 & $0 \%$ & 3 & $2 \%$ \\
\hline National identity & 0 & $0 \%$ & 6 & $8 \%$ & 0 & $0 \%$ & 6 & $4 \%$ \\
\hline Sense of belonging & 0 & $0 \%$ & 6 & $8 \%$ & 0 & $0 \%$ & 6 & $4 \%$ \\
\hline Cultural heritage & 0 & $0 \%$ & 3 & $4 \%$ & 0 & $0 \%$ & 3 & $2 \%$ \\
\hline Healthy life & 0 & $0 \%$ & 0 & $0 \%$ & 1 & $4 \%$ & 1 & $1 \%$ \\
\hline Punctuality & 0 & $0 \%$ & 0 & $0 \%$ & 1 & $4 \%$ & 1 & $1 \%$ \\
\hline Generosity & 0 & $0 \%$ & 0 & $0 \%$ & 1 & $4 \%$ & 1 & $1 \%$ \\
\hline Motherhood & 0 & $0 \%$ & 0 & $0 \%$ & 1 & $4 \%$ & 1 & $1 \%$ \\
\hline Enthusiasm & 0 & $0 \%$ & 0 & $0 \%$ & 1 & $4 \%$ & 1 & $1 \%$ \\
\hline Curiosity & 0 & $0 \%$ & 0 & $0 \%$ & 1 & $4 \%$ & 1 & $1 \%$ \\
\hline Kindness & 0 & $0 \%$ & 0 & $0 \%$ & 4 & $14 \%$ & 4 & $3 \%$ \\
\hline Happiness & 0 & $0 \%$ & 0 & $0 \%$ & 5 & $18 \%$ & 5 & $3 \%$ \\
\hline Efficiency & 0 & $0 \%$ & 0 & $0 \%$ & 1 & $4 \%$ & 1 & $1 \%$ \\
\hline Equality & 0 & $0 \%$ & 0 & $0 \%$ & 1 & $4 \%$ & 1 & $1 \%$ \\
\hline TOTAL & 45 & $100 \%$ & 77 & $100 \%$ & 28 & $100 \%$ & 150 & $100 \%$ \\
\hline
\end{tabular}




\section{Results of the frequency analysis}

As Table 1 shows, the most frequently used word related to moral values in the EYL textbook for Grade 4 is politeness $(22 \%)$ whereas other frequently occuring words are being helpful (11\%), friendliness" (9\%), caring (9\%), warm relationship $(9 \%)$, and loving family $(9 \%)$ respectively. In the texbook for Grade 5, the most frequently used word is being helpful (25\%) while other frequently occuring words include respecting others (13\%), caring $(12 \%)$, national identity $(8 \%)$, and sense of belonging $(8 \%)$ respectively. In the textbook Grade 6 , happiness $(18 \%)$ is the most frequently used word that showcases a moral value whilst other frequently occuring words include kindness (14\%),friendliness $(7 \%)$, and caring $(7 \%)$ respectively.

Table 1 also shows the total frequencies of words used related to moral values represented in the EYL textbooks for Grades 4, 5, and book 6. The results show that the most frequently used words related to moral values in the three textbooks are 'being helpful $(17 \%)$, politeness $(11 \%)$, and caring (10\%) consecutively.

\section{Results of narrative analysis}

In addition to frequency analysis, this study also employed narrative analysis to interpret more content or discursive interpretations of the text samples which represent moral values. The narrative analysis shows the representation ofthe most dominant value of being helpful or helping others in the textbooks below.

Text 1:

The board is dirty and it is full of writing. Miss Bertha wants Nurul to clean the board. Can Nurul help Miss Bertha? Of course she can. She likes the classroom clean (Grow with English Textbook Grade 4, p.9)

The situation portrayed in the text commonly occurs in a classroom where the board is dirty, and the teacher asks one of the students to clean the board.

Text 2

School canteen attendant Student

School canteen attendant

Student

School canteen attendant Student

School canteen attendant
In this situation, Miss Bertha, the teacher, has more power (social status: a teacher) to ask Nurul to clean the board. The textbook writers may want to emphasize that the teacher is the authority who can endorse an imperative to students. In terms of unequal social power, as a student, it is an obligation for Nurul to follow what her teacher asks her to do something (cleaning the board). The textbook writers use this statement: She likes the classroom clean which contains a positive 'affect' (Martin \& White 2005). This implies that Nurul is happy to do that without being forced. The act of cleaning the board may be Nurul's habit of cleaning the board regardless of the teacher's command or request. This discourse may also show the textbook writers' attitude towards helping more senior or respectful people or those with authority. The deployment of this attitudinal discourse can be an effective way of instilling the value of being helpful or helping others in primary school students or pupils. Classroom events can be used as case studies that the textbook writers can make use of in order to situate the teaching of moral values in classroom contexts. This is in line with what Shaaban (2005) contends that a classroom is a medium of moral value cultivation. Teachers need to take into account appropriate strategies for promoting and contextualizing these values in their classrooms.

As seen in Text 2, the school canteen initiates a dialog by asking "Can I help you?." This means that the canteen attendant offers a service help to the student. The student then answered "Yes" as an indication that the student accepted the attendant's offer. This text illustrates that helping people can also become a main job of someone. He/she earns money by giving help to others. In this context, the canteen attendant who helps serve the student. Despite asking for help, we, as costumers, should show respect and politeness to service attendants. The use of the word "would like" is intended to respect people and to make the dialogue sound more polite, while the word "please" expresses a polite request or question that is directed to the canteen attendant.
Politeness is created to build close relationship and avoid a clash or conflict or create social comfort among participants in the dialogue or conversation (De Jong et al., 2008). Thus, in the textbook, the textbook writers may want to signal moral messages to students so that they can have an awareness of building an interpersonal relationship with other
: Yes. What's special today?

: We have fried rice, noodles, and chicken soup. We also have iced tea, milk, coffee and orange juice.

: Let me see. I would like to have fried rice please.

: And for the drink?

: iced tea, please.

: So, it's fried rice and iced tea.

(Grow with English, Textbook Grade 5, p.20) people in school and outside the school,particularly when asking for and giving helps.

Text 3

School staff : Good morning Meilin. Can I help you?

Student : My teacher needs some paper. Do you have any?

School staff : Sure. Here you are.

Student : Thank you. 
School staff : You're welcome.

(Grow with English, Textbook Grade 6, p.9)

This dialogue (Text 3 ) reinforces the value of being helpful. The student tries her best to help her teacher ask for some paper from the school staff. The expression "Good morning, Meilin. Can I help you?" shows staff welcoming attitude to the student. The school staff wants to make sure that everyone is happy with her hospitality. The expression of "thank you" by the student after receiving the paper indicates that the student appreciates the staff help/hospitality. It is important to teach primary school students about the value of helping others and hospitality in early education. The dialogue seen in Text 3 above may emphasize how to ask for help politely and to give help to others with generous hospitality.

Lexical items, images, and selected language representing the textbook writers' attitudinal discourse

\section{Textbook: Grade 4}

Despite infusing moral content into visual depictions, the textbook writers also incorporate moral values into learning materials through particular lexical items in written texts. Visual representation and written text are both co-deployed to amplify the meaning. In the selected textbooks, the authors do not overtly indicate moral values of which teachers and students should be aware. These values are implicitly integrated into the learning materials. To make the analysis more comprehensive, we pick three genres as units of analysis; conversation text, narrative text, and note. These genres were selected because most of the lessons are presented through these genres. In addition, these genres represent moral values.

\section{Sample text \#1}

The following text tells the reader the differences in the ways to greet someone older than us and to greet our peers.

\section{Figure 1}

(Grow with English, Textbook Grade 4, p.4)

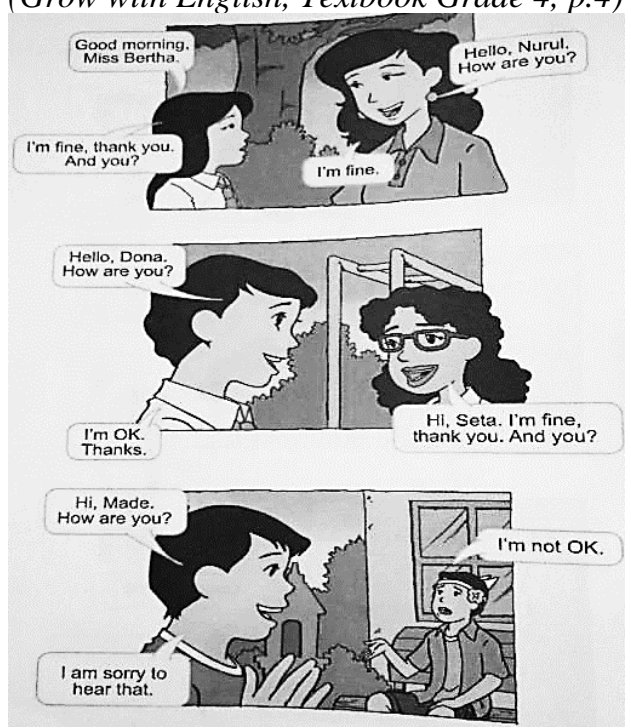

In the dialogue above, the textbook writers may intend to show students how to respect the older. Nurul, as the student, initiates the dialogue by greeting her teacher. In the Indonesian context, it is unethical when the younger does not initiate to greet the older when they meet up. In a high-culture context where individuals should conform to social expectations, the younger have to offer the seat they are occupying to the elder when there are no more unoccupied seats available. To some people, giving a seat to the elder may be viewed as a sign of humanity because the elder need to give top priority. As a younger person, it is a responsibility for the student to align herself to the accepted moral value. Thus, it is obligatory for the younger to show social respect to the elder. The expression "How are you?" by Miss Bertha indicates that she cares for her student and the question "And you?" by Nurul shows that she also cares for her teacher.

The textbook writers may assume that every student has to show care and attention to their peers (See Sample text \#1). This dialogue (see Figure 1) implicitly teaches students to show respect to their teachers inside and outside the classroom. It also implies that a teacher should show his/her care and respect to students. Thus, the textbook writers would possibly like to reinforce that showing respect to others regardless of age and social status can become an ethical norm in any social contexts.

Sample text\#2

This is a note written by Seta to express his apology to his best friend.

\section{Figure 2}

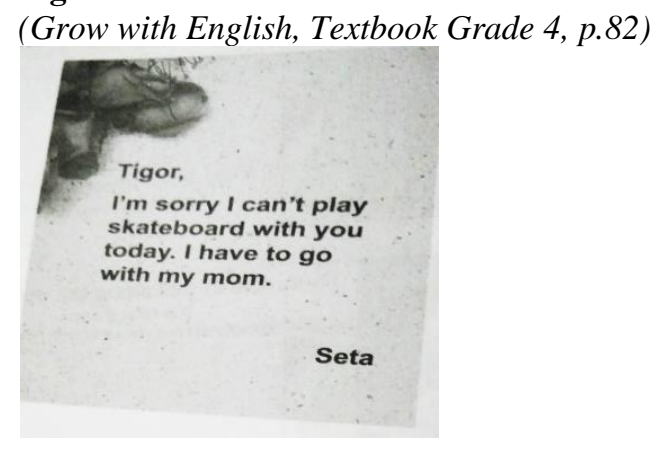

Although the genre does not seem authentic in today's digitally-mediate communication (texting a message through WhatApps), the textbook writers would like to show how to apologize when someone cannot fulfill their promise. The discourse of apology, "I'm sorry [apology] I can't play skateboard with you today [the planned activity]" indicates two sub-discourses: the discourse of apology and the discourse of the planned event. This plan could not be realized because there is an emergency that Seta has to go with his Mom: something urgent. The discourse of reasoning/justification should be provided in order to make a reasonable excuse. The 
lexical choice of "have to" indicates Seta's obedience to his mom. Playing skateboard can be done next time, but, when parents ask for help, in this context, the boy's mom wants him to go with her, he needs to prioritize this. Thus, the textbook writers may emphasize the value of obedience when parents ask children to do something instead of playing with their peers. Although the boy could not fulfill his promise, he still has to show respect to Tigor by writing a short message or letter that he could not keep his promise because of something urgent. Writing an apology message is a good choice to let his friend know about the situation. This moral value explicitly conveys the value of apology/respect for others. At that time, the boy might be in a hurry, and he could not meet his friend and told the situation directly. In other case, children may not have a gadget or access to the Internet, so texting this message is not possible. Thus, Seta decided to write a message to Tigor.

\section{Textbook: Grade 5}

To begin with, sample text \# 1 talks about introducing a new friend as classmate in school.

\section{Figure 3}

Introducing a New Friend in School (Grow With English, Textbook Grade 5, p.1)

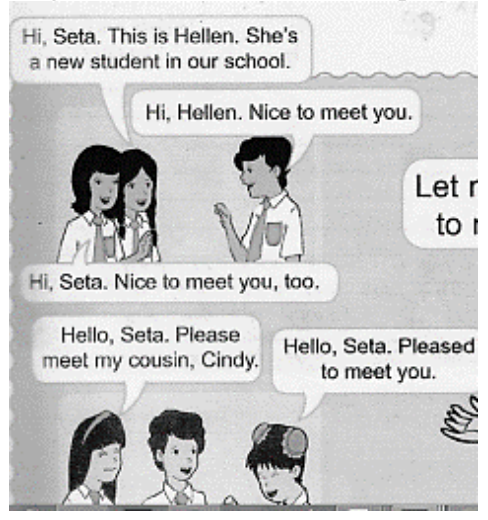

In the text above, two visual images show the way to introduce a new student/friend to others. It is important to note that the dialogue was presented to make readers (teacher and students) aware that the expressions of greetings; "hi, hello, nice to meet you and pleased to meet you"are signs of welcome or recognition in social practice. This dialogue also gives the value of respecting for another person; and encourages teachers and students to practice it in school. In this context, respect means a social recognition that we obtain from other people (Baumann, 2007). The characteristics of respect are identified into two things: attention and response (Noddings, 2008). In other words, greetings can be a way of building a close social distance so that the conversation or dialogue looks friendly, enjoyable and relaxed in that situation. thanking.

\section{Figure 4}

Thanking (Grow With English, Textbook Grade 5, p.5)

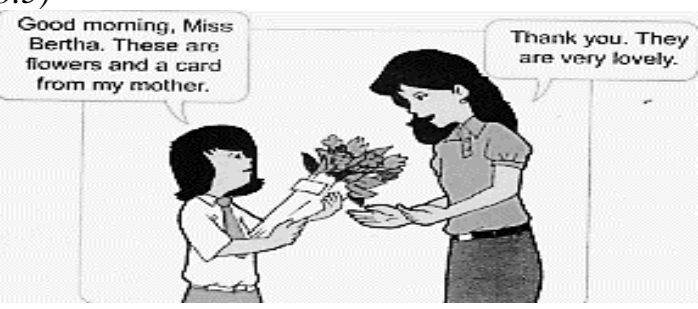

This provides a model for a teacher to appreciate a student's gift by compliment and thanking. Expressing gratitude is defined as a kind of appreciation for something that he or she has done which refers to a thought that is given by the human being has endued a favor and grace (Robbins, 2014). This value may be derived from personal and social interactions, participation, and engagement between a student and a teacher. It is obvious that the image and dialogue (Figure 5) depict a student and a teacher who are interacting in school. In the dialogue, a student is giving a flower gift and a card from her mother for her teacher, then the teacher accepted and respected for her mother's flower gift. The teacher responded: "Thank you. They are very lovely" as a kind of appreciation and acceptance what the student gives to her. This also indicates the value of respect for her student by saying "thank you". The use of "thank you" signifies a polite expression when acknowledging a gift, service, or compliment, or accepting an offer. It is a good way to model moral values directly to the student in school because teaching morality requires repeated action so as to enhance students' ethical capabilities (Rissanen et al., 2018).

\section{Book 6}

To begin with, sample Text \# 1 (Page 9) talks about the students-staff conversation in the school office.

\section{Samle Text \# 1}

Figure 5

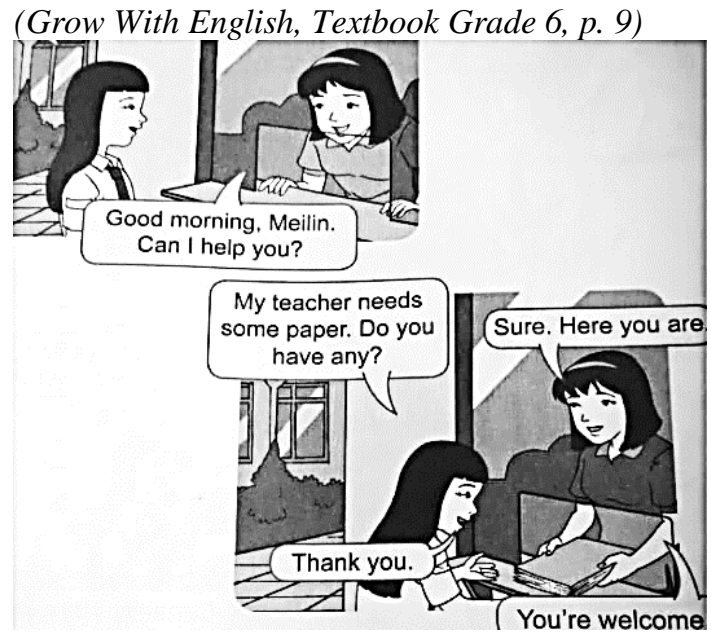


The visual and written texts depict an excellent service should be taught at school. The lady as a school staff happily offers her help. This is because of her job to serve people. The lesson of hospitality is emphasized here. On another occasion, the student tries her best to help her teacher ask for some paper while the lady does the same thing by providing the paper. The lexical choices "Good morning, Meilin. Can I help you?" show the staff welcoming attitude to the student. Because of her job dealing with people, it is a must to do for her to have this kind of attitude. She should ensure that everyone is happy with her hospitality. The expression of "thank you" by the student after receiving the paper indicates that she appreciates the staff's job. This is important to teach primary school students about this value in their early education.

\section{Sample text \# 2 \\ Figure 6}

(Grow With English, Textbook Grade 6, p. 9)

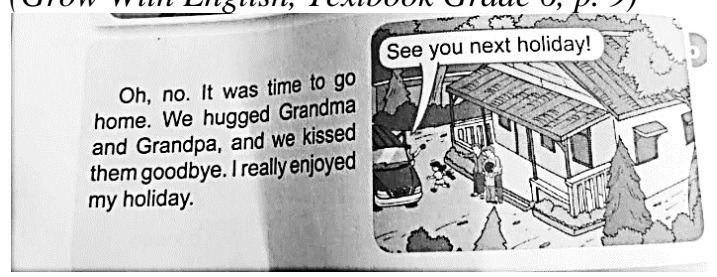

The images implicitly teach children about farewell and family bonding. The acts of hugging and kissing grandma and grandpa seen in Figure 7 show children positive behaviors: love and caring for their family. This action represents moral values through eliciting a social event that leads to social judgments (Feng, 2017). Ignoring this behavior may receive negative judgment from society that holds the belief of a social communal event.

\section{Sample Text \# 3 \\ Picture 7}

(Grow with English, Textbook Grade 6, p.118)

We stayed at home in the
evening. Mom and Dad watched
their favorite TV program, my sister
played computer games and I read
my new novel. After that, I studied
and prepared my lessons. Finally, I
went to bed at around 9:00.

This sample text depicts a kid's activities on Sunday night. It can be seen from the text that Sunday night is perceived as the rest of holiday and a starting point to face Monday. The activities such as watching favorite TV program, playing computer games, and reading novel show their activities at leisure time. However, the textbooks author may want to emphasize that Sunday night is also our time to plan what we are going to do on Monday. The sentences: I studied, prepared my lessons, and went to bed at around 09.00 indicate that children should be ready for their Monday. These lexical choices evoke moral values of time management for kids. They have to balance their life activities between study, play, and break.

As the majority of the pictures shows in the textbook are real or non-fictional in social event and activity contexts. Non-fiction or authentic information are intended to support learners in learning language in real-life situations (Rindawati et al., 2014). The aim of the author may be to guide learners to learn activities through a myriad of texts and bring them to their actual situations. The ideological content of the textbooks emphasizes three dominant values, such as helping others, behaving politely, and caring for others. In high-culture contexts, such as Indonesia, conforming to social expectations (e.g., showing respect to the elder) is a shared social norm or value that Indonesian society holds. As both verbal and visual texts presented earlier, the textbook writers may attempt to conform to social expectations that most of the Indonesian communities value.

\section{CONCLUSION}

The goal of the present critical discourse study is to examine the representation of moral values in the EYL textbooks used in Indonesian elementary schools. Findings showed that helping others, being polite, and caring are mostly predominantly depicted in the textbooks through both verbal and non-verbal texts. This study attempts to provide a better understanding of value representations in different social contexts, such as a school canteen, school, and home. It was found that the textbook writers put greater emphasis on three values: helping others, behaving politely, and caring. They may want to instill these values in young learners or pupils because such values are the basis for interacting with others in real-life contexts. They may wish to demonstrate that the majority of Indonesian people who believe in high-culture communality values, such as helping others, being polite, and caring. In high-culture contexts, such as in Indonesia, people have to nurture main characters of being helpful, polite, and caring because in social interactions, people need one another. Such values may be a social sign of humanity or civilized culture.

Drawing on our empirical evidence, both curriculum and textbook designers need to be fully aware of moral values and moral sensitivity so that they can present balanced moral values in language textbooks. It is imperative for textbook writers to avoid focusing dominant values that society may hold, but textbook writers may infuse more important moral values in which children should instill. It is obvious that language textbooks teach not merely language skills but also values, such as moral or character values. It is undeniable that teaching moral values to children in English language classroom 
contexts cannot be avoided because this moral issue is part of a social phenomenon across the globe. More future studies may focus on the representation of moral values in nationally- and internationally-used language textbooks. Such empirical research may compare the representation of moral values in two types of language textbooks.

\section{REFERENCES}

Akbari, R., \& Tajik, L. (2012). Second-language teachers' moral knowledge base: A comparison between experienced and less experienced, male and female practitioners. Journal of Moral Education, 41(1), 39-59. https://doi.org/10.1080/03057240.2011.630384

Alwasilah, A. C. (2012, November). It's time to revitalize Indonesian teaching, The Jakarta Post.

Baumann, P. (2007). Persons, human beings, and respect. Polish Journal of Philosophy, 2, 5-17.

Copland, F., Garton, S., \& Burns, A. (2014). Challenges in teaching English to young learners: Global perspectives and local realities. TESOL Quarterly, 48, 738-762. https://doi.org/10.1002/tesq.148

Canh, L. V. (2018). A critical analysis of moral values in Vietnam-produced EFL textbooks for upper secondary schools. In H. P. Widodo, M. R. G. Perfecto, L. V. Canh, \& A. Buripakdi (Eds.), Situating moral and cultural values in ELT materials: The Southeast Asian context. Springer International Publishing AG.

De Jong, M., Theune, M., \& Hofs, D. (2008). Politeness and alignment in dialogues with a virtual guide. In Proceedings of the 7th international joint conference on Autonomous agents and multiagent systems-Volume 1 (pp. 207-214). https://dl.acm.org/doi/10.5555/ 1402383.1402416

Doan, H. D. (2005). Moral education or political education in the Vietnamese educational system? Journal of Moral Education, 34(4), 451-463. https://doi.org/10.1080/03057240500414733

Feng, D. W. (2017). Infusing moral education into English language teaching: an ontogenetic analysis of social values in EFL textbooks in Hong Kong. Discourse: Studies in the Cultural Politics of Education, 47(1), 63-77. https://doi.org/10.1080/01596306.2017.135680 6

$\mathrm{Gu}, \mathrm{X}$. (2016). Evaluation in US and Japanese history textbooks. Text \& Talk, 36, 221-243.

Halliday, M. A. K. (1978). Language as social semiotic: The social interpretation of language and meaning. Edward Arnold.

Hawanti, S. (2014). Implementing Indonesia's English language teaching policy in primary schools: The role of teachers' knowledge and beliefs. International Journal of Pedagogies and Learning, 9, 162-170.

https://doi.org/10.1080/18334105.2014.110820 29

Hermawan, B., \& Noerkhasanah, L. (2012). Traces of cultures in English textbooks for primary education. Indonesian Journal of Apllied Linguistics, 1(2), 49-61. https://doi.org/10.17509/ijal.v1i2.84

Huda, N. (1999). Language learning and teaching, issues and trends. IKIP Malang.

Johnston, B. (2003). Values in English language teaching. Lawrence Erlbaum.

Kemendiknas. (2011). Pedoman pelaksanaan pendidikan karakter [Handbook for character education]. Jakarta Puskurbuk.

Lestariyana, R. P. D., \& Widodo, H. P. (2018). Engaging young learners of English with digital stories: Learning to mean. Indonesian Journal of Applied Linguistics, 8, 489-495. https://doi.org/10.17509/ijal.v8i2.13314

Liu, Y. (2005). Discourse, cultural knowledge and ideology: A critical analysis of Chinese language textbooks. Pedagogy, Culture and Society, 13(2), 233-264. https://doi.org/10.1080/14681360500200225

Lovat, T. (2017). Values education as good practice pedagogy: Evidence from Australian Empirical research. Journal of Moral Education, 46(1), 88-96.

https://doi.org/10.1080/03057240.2016.126811 0

Ma, A. (2012). A study of the shaping of the 'emotion and attitude' domain in the new English language curriculum of China through an EFL textbook. Pedagogy, Culture \& Society, 20(2), 231-250. https://doi.org/10.1080/14681366.2012.688764

Mambu, J. E. (2015). Challenges in assessing character education in ELT: Implications from a case study in a Christian university. TEFLIN Journal, 26, 183-208. http://dx.doi.org/10.15639/teflinjournal.v26i2/ 183-208

Martin, J. R., \& White, P. (2005). The language of evaluation: Appraisal in English. Palgrave Macmillan.

Noddings, N. (2008). Caring and moral education. In Nucci, P. L \& Narvaez, Darcia (Eds.), Handbook of Moral and Character Education 9 (pp. 161-174). Routledge.

Orton, J. (2010). Culture and English materials. In H. P. Widodo \& L. Savova (Eds.), The Lincom guide to ELT materials design and development: Theory and practice (pp. 215228). Lincom Europa

Parlindungan, F., Rifai, I., \& Safriani, A. (2018). The representation of Indonesian cultural diversity in middle school English textbooks. Indonesian Journal of Applied Linguistics, 
8(2), 289-302.

https://doi.org/10.17509/ijal.v8i2.13276

Pusat Kurikulum [Center for Curriculum

Development]. (2010). Pengembangan

pendidikan budaya dan karakter bangsa, character education development.

Kementerian Pendidikan Nasional, Badan

Penelitian dan Pengembangan, Pusat

Kurikulum.

Putra, D. A., \& Lukmana, I. (2017). Text complexity in senior high school English textbooks: A systemic functional perspective. Indonesian Journal of Applied Linguistics, 7(2). 436-444. https://doi.org/10.17509/ijal.v7i2.8352

Qoyyimah, U. (2016). EFL teachers' reconciliation with moral forces brought into curriculum. Proceedings of the 14th AsiaTEFL@11th FEELTA International Conference on Language Teaching Vladivostok, June 30-July 02, 129-134.

Rindawati, Ikhsanudin, \& Wardah. (2014). An analysis on English textbook "Bahasa Inggris: When English rings the bell". Jurnal Pendidikan dan Pembelajaran Khatulistiwa, 3(9), 1-13. http://jurnal.untan.ac.id/index.php/jpdpb/article /view/6871/7082

Rissanen, I., Kuusisto, E., Hanhimäki, E. \& Tirri, K. (2018).The implications of teachers' implicit theories for moral education: A case study from Finland. Journal of Moral Education, 47(1) 63-77. https://doi.org/10.1080/03057240.2017.137424 4

Robbins, B. D. (2014). Joyful thinking-thanking: A reading of Heidegger's "What is called thinking?". Janus Head: Journal of Interdisciplinary Studies in Literature, Continental Philosophy, Phenomenological Psychology, and the Arts, 13(12), 13-21. http://www.janushead.org/index.html

Shaaban, K. (2005). A proposed framework for incorporating moral education into the ESL/EFL classroom. Language, Culture and Curriculum, 18(2), 201-217. https://doi.org/10.1080/07908310508668742

Setyono, B., \& Widodo, H. P. (2019). The representation of multicultural values in the Indonesian Ministry of Education and Cultureendorsed EFL textbook: A critical discourse analysis. Intercultural Education, 30(4), 383397. https://doi.org/10.1080/14675986.2019. 1548102

Sulfasyah., Bahri, A., \& Saleh, S. F. (2018). Writing lessons in grade 1 Indonesian thematic textbooks: A content analysis. Indonesian
Journal of Applied Linguistics, 7(3). 495-503. https://doi.org/10.17509/ijal.v7i3.9789

Sulistiyo, U., Haryanto, E., Widodo, H. P., \& Elyas, T. (2019). The portrait of primary school English in Indonesia: Policy recommendations. Education 3-13, 47, 1-15. https://doi.org/10.1080/03004279.2019.168072 1

Suparno, P. (2011, November). Character development and national building. The Jakarta Post.

The Curriculum Development Council. (2012). Moral and national education curriculum guide (Primary 1 to Secondary 6). HKSAR Government, Curriculum Development from Pre-Primary to Senior Secondary.

Thongrin, S. (2012). EFL writing instruction. In A. Wiriyajitra (Ed.), Looking back, looking forward: English instruction (pp. 139-177). DK today.

Widodo, H. P. (2016). Language policy in practice: Reframing the English language curriculum in the Indonesian secondary education sector. In R. Kirkpatrick (Ed.), English language education policy in Asia (pp. 127-151). Springer.

Widodo, H. P. (2018). A critical micro-semiotic analysis of values depicted in the Indonesian Ministry of National Education-endorsed secondary school English textbook. In H. P. Widodo et al. (eds.), Situating moral and cultural values in ELT materials: The Southeast Asian context (pp. 131-152). Springer International Publishing AG.

Widodo, H. P., Perfecto, M. R. G., Canh, L. V., \& Buripakdi, A. (Eds.). (2018). Situating moral and cultural values in ELT materials: The Southeast Asian context. Springer International Publishing AG.

Xiong, T. (2012). Essence or practice? Conflicting cultural values in Chinese EFL textbooks: A discourse approach. Discourse: Studies in the Cultural Politics of Education, 33(4), 499-516. https://doi.org/10.1080/01596306.2012.692958

Xiong, T., \& Qian, Y. (2012). Ideologies of English in a Chinese high school EFL textbook: A critical discourse analysis. Asia Pacific Journal of Education. 32(1), 75-92.

https://doi.org/10.1080/02188791.2012.655239

Zein, M. S. (2017). To postpone or not to postpone? Examining access policy on early foreign language learning from second language acquisition and language planning and policy perspectives. Applied Linguistics Review, 8(4) 419-439. https://doi.org/10.1515/applirev2016-1044 